Krzysztof Knop ${ }^{1}$

\title{
ANALIZA I OCENA WYNIKÓW Z PROCESÓW KONTROLI WIZUALNEJ JAKO SPOSÓB DOSKONALENIA PROCESU PRODUKCYJNEGO PODUSZEK POWIETRZNYCH
}

\begin{abstract}
Streszczenie: Prezentowany artykuł to case-study z doskonalenia procesu produkcyjnego poduszek powietrznych, gdzie do zainicjowania doskonalenia wykorzystano wyniki z procesów kontroli wizualnej badanego wyrobu. W artykule przedstawiono wyniki analizy struktury niezgodności badanego wyrobu, na podstawie których zidentyfikowano niezgodności krytyczne. W tym celu wykorzystano diagram Pareto-Lorenza. Najczęściej występująca niezgodność badanego wyrobu to rysy i zadrapania na powierzchni poduszki powietrznej, która to niegodność wykrywana jest za pomocą kontroli wizualnej. W celu analizy niezgodności krytycznej wykorzystano takie metody, jak: 5W1H, 5WHY. Metoda 5W1H pozwoliła lepiej rozpoznać badany „krytyczny” problem. Z kolei dzięki metodzie 5WHY, a dokładniej jej wersji w postaci diagramu WHY-WHY, wskazano na przyczynę źródłową problemu, w odniesieniu do której zaproponowano działania zaradcze. Przeprowadzone analizy dowiodły, że dzięki analizie wyników z kontroli jakości (kontroli wizualnej) można ograniczyć występowanie problemów jakościowych, a tym samym udoskonalić proces produkcyjny.
\end{abstract}

Słowa kluczowe: kontrola wizualna, doskonalenie, analiza źródłowa, branża motoryzacyjna, poduszki powietrzne

\section{Wprowadzenie}

Kontrola wizualna jest rodzajem kontroli jakości, który polega na określeniu właściwości wyrobu z pomocą „wizualnych” sposobów [1]. Kontrola wizualna przyjmuje różne formy: kontroli wzrokowej (organoleptycznej), kontroli wizualnej wspomaganej, kontroli wizualnej automatycznej (widzenie maszynowe), badań wizualnych (VT) [2]. Udział pracy człowieka w tych procesach kontrolnych jest różny: bardzo duży (kontrola wzrokowa) lub znaczenie ograniczony - w przypadku widzenia maszynowego, gdzie rola człowieka ogranicza się jedynie do nadzorowania samego procesu oceny [3]. Ogólnie, kontrola wizualna znajduje zastosowanie dla kontroli cech niemierzalnych lub mierzalnych wyrobu, w przypadku, gdy pomiar takich cech jest utrudniony lub ekonomicznie nieuzasadniony [4]. Mimo rozwoju metod pomiarowych bazujących na coraz bardziej obiektywnych przyrządach pomiarowych, nadal w wielu przedsiębiorstwach dominującą metodą kontroli jakości jest kontrola wykorzystująca wyłącznie zmysły człowieka [5]. Mimo swojej niedoskonałości i dużego ryzyka niewykrycia niezgodności lub ich nieodpowiedniej oceny przez pracownika (kontrolera) producenci wyrobów $\mathrm{z}$ różnych branży (w szczególności $\mathrm{z}$ branży metalowej) nadal powszechnie stosują tradycyjne

1 Dr inż., Politechnika Częstochowska, Wydział Zarządzania, Katedra Inżynierii Produkcji i Bezpieczeństwa, kryzsztof.knop@wz.pcz.pl 
wzrokowe metody kontroli jakości, wspomagane jedynie pomiarami pomocniczymi urządzeń pomiarowych [6].

Kontrola wizualna wpływa na skuteczność oraz efektywność procesu produkcyjnego. Kontrola jakości (kontrola wizualna) jest procesem, który sensu stricto nie tworzy wartości dodanej [7], nie zmienia bowiem przedmiotu kontroli, jej wykonanie wymaga odpowiednich stanowisk roboczych, nakładów pracy i pochłania czas [8]. Kontrola (wizualna) jakości jest natomiast procesem pomocniczym, który w sposób pośredni może tworzyć wartość dodaną (do procesów, wyrobów, metod pracy, itd.). Kontrola (wizualna) jakości może być istotnym narzędziem współtworzenia wartości dodanej poprzez proponowanie ulepszeń i usprawnień, tzn. działań, które prowadzą do pozytywnych zmian w zakresie jakości procesu, produktu i warunków eksploatacji maszyn [9]. Celem końcowym kontroli wizualnej (jakości) powinno być podniesienie jakości oraz sprawności działania przedsiębiorstwa przez usuwanie nieprawidłowości, jej przyczyn i źródeł oraz pobudzanie działań doskonalących poprzez podanie przykładów dobrego działania lub zmianę obowiązujących standardów, procedur postępowania. Nowoczesna kontrola wizualna (jakości) powinna stanowić podstawowe źródło informacji zwrotnej o procesie produkcyjnym, które pozwala doskonalić produkcję oraz ograniczać koszty [10].

Prezentowany artykuł przedstawia rezultat analizy wyników z procesów kontroli wizualnej, która stanowiła punkt wyjścia do udoskonalenia procesu produkcyjnego badanego wyrobu - poduszka powietrzna. Kontrola wizualna zajmuje istotną rolę $\mathrm{w}$ ocenie jakości wyrobu, jakim są poduszki powietrzne, w badanym przedsiębiorstwie, oraz dostarcza cennych informacji przydatnych w procesie doskonalenia. Dane z kontroli wizualnej poddano analizie ilościowej i jakościowej z wykorzystaniem takich narzędzi i metod, jak: diagram Pareto-Lorenza, metoda 5W1H, diagram WHY-WHY, celem udoskonalania procesu produkcyjnego badanego wyrobu.

\section{Wyniki badań}

\subsection{Analiza ilościowa wyników z kontroli wizualnej}

W przedsiębiorstwie produkującym poduszki powietrzne dokonano analizy ilościowej niezgodności pojawiających się na przestrzeni jednego roku, zidentyfikowanych na linii montażu. W tym celu wykorzystano jedno z narzędzi zarządzania jakością, tj. diagram Pareto-Lorenza [11, 12]. Dokonano analizy 10 najczęściej występujących niegodności badanego wyrobu. W oparciu o uzyskane o posortowane malejąco dane w zakresie liczby wystąpień niezgodności obliczono udziały procentowe oraz ich wartość skumulowaną. Wyniki analizy Pareto-Lorenza zostały przedstawiono w tabeli 1. 
Tab. 1. Analiza Pareto-Lorenza dla niezgodności poduszek powietrznych

\begin{tabular}{|c|c|c|c|}
\hline $\begin{array}{l}\text { Lp./Symbol } \\
\text { niezgodności }\end{array}$ & Nazwa niezgodności & $\begin{array}{c}\text { Udzial } \\
\text { procentowy } \\
{[\%]}\end{array}$ & $\begin{array}{c}\text { Wartość } \\
\text { skumulowana } \\
{[\%]}\end{array}$ \\
\hline 1 & $\begin{array}{l}\text { Widoczne rysy i zadrapania na } \\
\text { powierzchni poduszki powietrznej }\end{array}$ & 41,99 & 41,99 \\
\hline 2 & $\begin{array}{l}\text { Źle przymocowany kabel do } \\
\text { generatora }\end{array}$ & 27,84 & 69,83 \\
\hline 3 & Ułamane piny na generatorze & 7,91 & 77,75 \\
\hline 4 & $\begin{array}{l}\text { Słabo skręcony moduł kierownicy na } \\
\text { skręcarce }\end{array}$ & 7,17 & 84,92 \\
\hline 5 & $\begin{array}{c}\text { Niewłaściwie złożona poduszka } \\
\text { powietrzna }\end{array}$ & 5,21 & 90,13 \\
\hline 6 & Uszkodzony generator & 3,45 & 93,58 \\
\hline 7 & $\begin{array}{c}\text { Nie odbijająca się sprężyna klaksonu } \\
\text { w module kierownicy }\end{array}$ & 2,70 & 96,28 \\
\hline 8 & Uszkodzony moduł kierownicy & 1,96 & 98,23 \\
\hline 9 & Brak szwu na poduszce powietrznej & 1,58 & 99,81 \\
\hline 10 & Brak wszystkich śrub w obudowie & 0,19 & 100,00 \\
\hline \multicolumn{2}{|r|}{ Suma } & 100 & $\mathbf{x}$ \\
\hline
\end{tabular}

Źródto: Opracowanie własne

Na podstawie wyników z tabeli 1 sporządzono diagram Pareto-Lorenza, który przedstawia rys. 1 .

$\mathrm{Z}$ rys. 1 wynika, że za 69,83\% problemów jakościowych odpowiadają dwie niezgodności z 10 (tj. 20\% przyczyn), tj.: 1 -niezgodności estetyczne na powierzchni poduszki powietrznej, 2 -źle przymocowany kabel do generatora. 5 niezgodności z 10 (50\%) stanowiło aż 90,13\% wszystkich problemów jakościowych, a są to oprócz pierwszych dwóch, także: 3 - ułamane piny na generatorze, 4 - słabo dokręcony moduł kierownicy, 5 - niewłaściwie złożona poduszka powietrza. Warto zauważyć, że dwie najrzadziej występujące niezgodności stanowiły zaledwie ok. $1 \%$ wszystkich występujących problemów jakościowych, a były to: 9 - brak szwu na poduszce powietrznej, oraz 10 - brak wszystkich śrub w obudowie. 


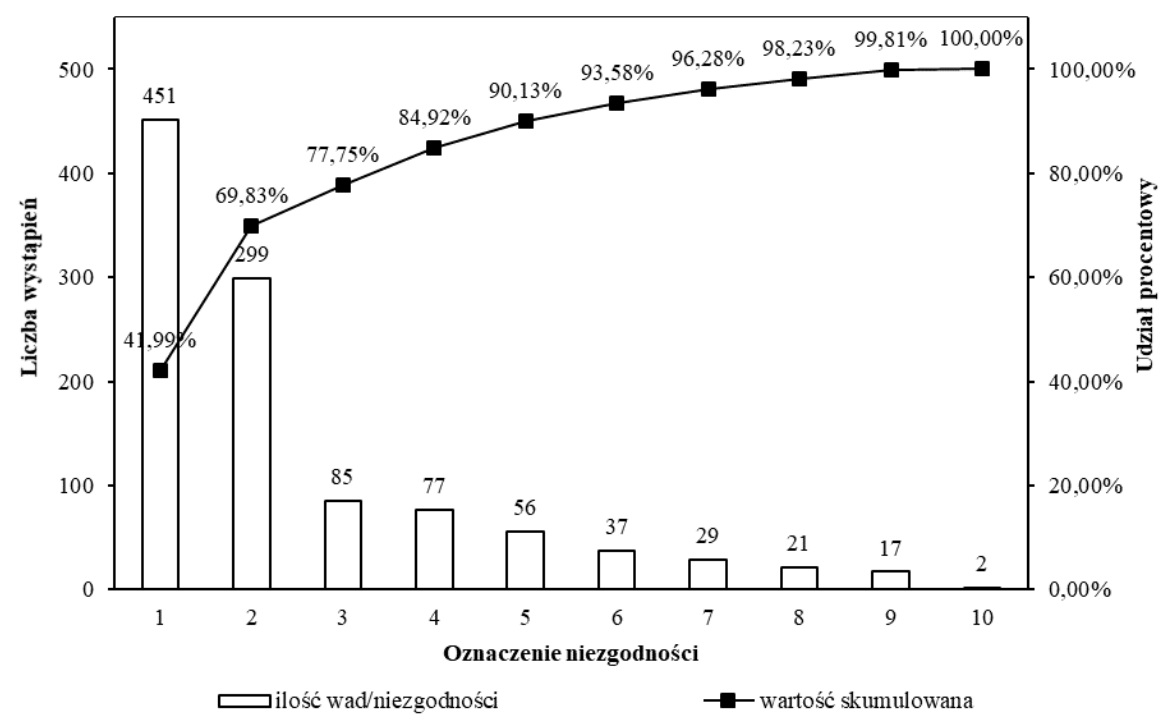

Rys. 1. Diagram Pareto-Lorenza dla analizy struktury niezgodności w procesie montażu poduszek powietrznych

Źródto: Opracowanie własne

\subsection{Analiza jakościowa wyników $\mathrm{z}$ kontroli wizualnej}

Analiza Pareto-Lorenza pozwoliła wskazać na niezgodności krytyczne (najczęściej występujące) poduszek powietrznych w okresie jednego roku. Najczęściej występującą niezgodnością, którą tym samym należy zająć się w pierwszej kolejności jest niezgodność estetyczna poduszki powietrznej, która wykrywana jest sposobem wizualnym. Aby lepiej rozpoznać stwierdzony „krytyczny” problem wykorzystano metodę $5 \mathrm{~W} 1 \mathrm{H}$, która polega na zadawaniu pięciu pytań zaczynających się na literę „W”: what (co?), when (kiedy?), where (gdzie?), who (kto?), which (który?), oraz jednego pytania zaczynającego się na literę „H”: how (jak?) [13, 14]. Wyniki analizy badanego problemu metodą $5 \mathrm{~W} 1 \mathrm{H}$ przedstawiono w tabeli 2.

Aby znaleźć przyczynę źródłową wystąpienia rys i zadrapań na powierzchni poduszek powietrznych dla kierowcy skorzystano z metody $5 \mathrm{WHY}$, która polega na zadawaniu pięciu pytań „dlaczego”. Odpowiadając na każde z pytań „dlaczego” można dojść do źródła problemu. Analizy 5 WHY można również dokonać za pomocą drzewka WHY-WHY [14], które ma tą zaletę nad klasyczną analizą 5WHY, że problem można analizować wieloaspektowo (z punktu widzenia różnych przyczyn). Tą wersję metody 5WHY (tj. diagram WHY-WHY) wykorzystano a wyniki jej zastosowania zaprezentowano na rysunku 2. 


\section{Tab. 2. Wyniki analizy 5 W1H dla doktadniejszego rozpoznania problemu porysowanych} poduszek powietrznych

\begin{tabular}{|l|l|}
\hline Linia & BMW 0360 \\
\hline Stanowisko & Wszystkie stanowiska montażowe i kontrolne \\
\hline Data & 18.05 .2018 \\
\hline $\begin{array}{l}\text { Zdarzenie } \\
\text { wstępne }\end{array}$ & $\begin{array}{l}\text { Na powierzchni poduszki powietrznej dla kierowcy zauważono zadrapania oraz } \\
\text { rysy. }\end{array}$ \\
\hline What & Problem dotyczy zadrapań oraz rys na poduszce powietrznej dla kierowcy. \\
\hline When & Znaleziono 27 sztuk wyrobu z takimi rysami w ciągu jednego tygodnia. \\
\hline Where & $\begin{array}{l}\text { Problem stwierdzono na poduszkach powietrznych montowanej do samochodu } \\
\text { BMW. }\end{array}$ \\
\hline Who & $\begin{array}{l}\text { Problem wystąpił na wszystkich stanowiskach montażowych i kontrolnych } \\
\text { u wszystkich pracowników na każdej ze zmian. Pracownicy na stanowiskach } \\
\text { zapoznali się z instrukcją służącą detekcji problemu. }\end{array}$ \\
\hline Which & $\begin{array}{l}\text { Zdarzenie ma miejsce regularnie, stwierdzono jednocześnie, że mogło wystąpić na } \\
\text { każdym ze stanowisk. }\end{array}$ \\
\hline How & $\begin{array}{l}\text { Podczas kontroli końcowej pracownik musi kontrolować każdą sztukę. Jeśli } \\
\text { zauważy sztukę z rysami, zadrapaniami bądź innymi zauważalnymi defektami to } \\
\text { musi ją uznać jako NOK i odłożyć na półkę z brakami. Wpływa to na spadek } \\
\text { wydajności pracy. }\end{array}$ \\
\hline $\begin{array}{l}\text { Zdarzenie } \\
\text { sprawdzone }\end{array}$ & $\begin{array}{l}\text { Podczas kontroli wizualnej powierzchni poduszek powietrznych zauważono } \\
\text { zadrapania oraz rysy. Problem dotyczył wszystkich stanowiskach montażowych } \\
\text { i kontrolnych. Problem został wykryty przez pracowników obsługujących te } \\
\text { stanowiska, którzy mogli jednocześnie mieć wpływ na jego powstanie. Detekcja } \\
\text { problemu oraz jego klasyfikacja wpływa na spadek wydajności pracy } \\
\text { (samokontrola). }\end{array}$ \\
\hline
\end{tabular}

Źródto: Opracowanie własne

W wyniku analizy WHY-WHY zidentyfikowano potencjalne przyczyny źródłowe problemu, które następnie zweryfikowano. W efekcie weryfikacji znaleziono jedną faktyczną przyczynę źródłową, którą uznano, za podstawową przyczynę rozpatrywanej niezgodności.

Po pierwszej weryfikacji przyjrzano się: maszynom, materiałowi wykonania poduszki powietrznej, procesowi montażu oraz transportowaniu poduszek. Maszyna mogła spowodować powstanie niezgodności poprzez stare oprzyrządowanie maszyny, które poprzez swoje zużycie mogły powodować zarysowania. Firma nie wymieniła starego oprzyrządowania, co było spowodowane wprowadzonym planem oszczędnościowym. Przeanalizowano także serwis, który mógł być rzadko przeprowadzany przez brak wystarczającej liczby mechaników. Po przeanalizowaniu maszyny okazało się, że zamontowane oprzyrządowanie pomimo swojego dużego zużycia nie miało wpływu na zarysowania poduszki, tak samo jak częste awarie spowodowane dość rzadkimi serwisami. 


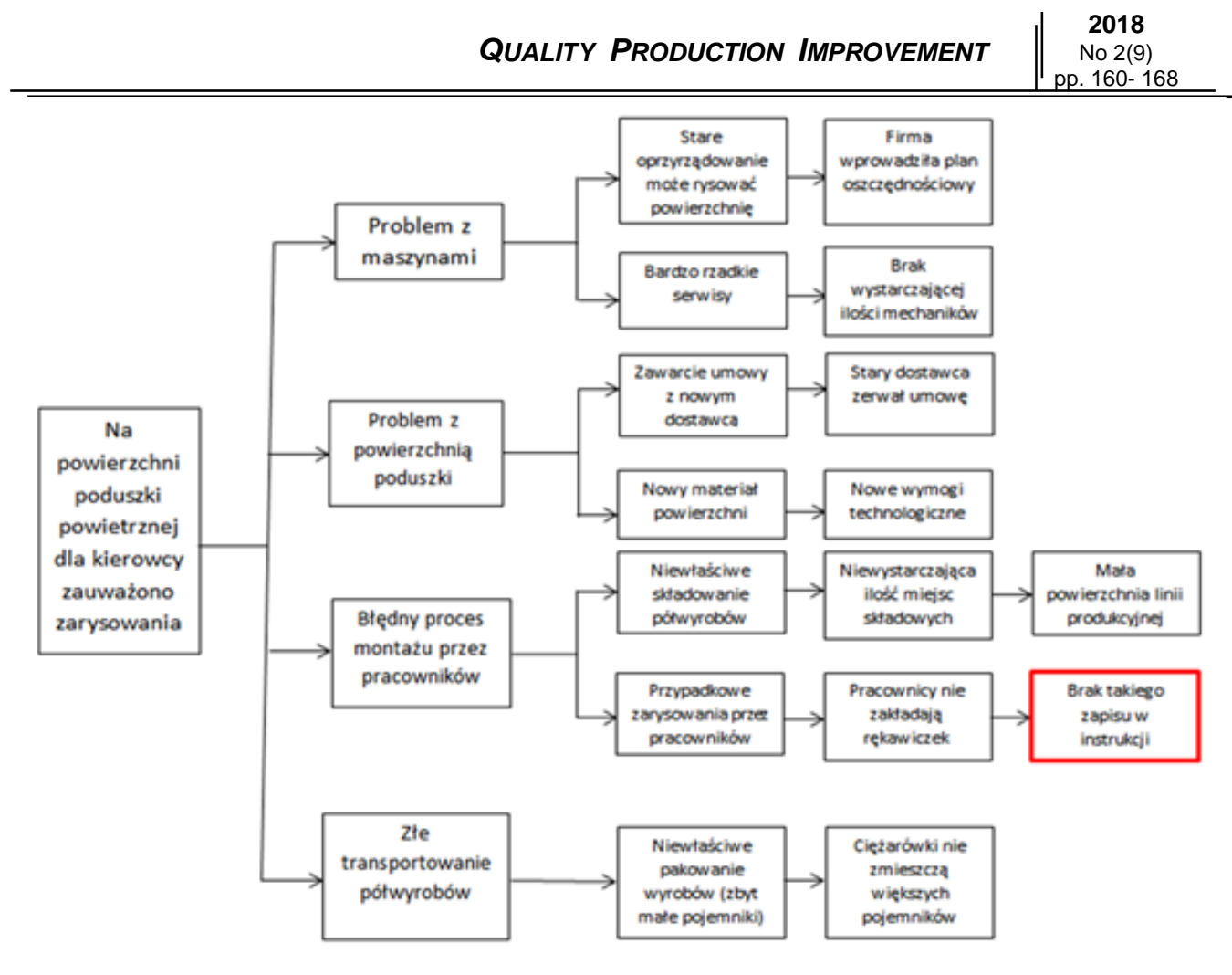

Rys. 2. Diagram WHY-WHY dla analizy przyczyn niezgodności estetycznych poduszek powietrznych

Źródto: Opracowanie własne

Następnie przyjrzano się materiałowi, $\mathrm{z}$ jakiego wykonana jest poduszka powietrzna. Zbadano nowy materiał wykonania poduszki powietrznej, podyktowany nowymi wymogami technologicznymi. Nowy materiał mógł być bardziej podatny na zarysowania. Przeanalizowano także nowego dostawcę, który niedawno zaczął dostarczać komponenty, ponieważ dotychczasowy kontrahent zerwał umowę. Okazało się, że jakość komponentów nowego dostawcy jest identyczna, jak poprzedniego. Natomiast nowy materiał poduszki powietrznej wykonany jest z innej powłoki, lecz nie ma to wpływu na zarysowania. Następnym czynnikiem, który mógł mieć wpływ na powstanie niezgodności był transport komponentów. $Z$ analizy wynikło, że komponenty powinny być przewożone w większych pojemnikach, co minimalizowałoby ryzyko powstawania niezgodności estetycznych. Komponenty były transportowane $\mathrm{w}$ mniejszych pojemnikach, ponieważ kontrahenci dysponowali mniejszymi ciężarówkami, które nie zmieściłyby większych pojemników. Przeprowadzono testy transportowania i nie zauważono jednak różnic pomiędzy transportem w małych i dużych pojemnikach. Ostatnim czynnikiem, który mógł mieć wpływ na niezgodność jest montaż samej poduszki powietrznej. Przenalizowano 
proces składowania półwyrobów pomiędzy poszczególnymi stanowiskami operacyjnymi. Okazało się, że poprzez niewystarczającą powierzchnię linii montażowej nie ma odpowiedniej ilości miejsc składowych na półwyroby. Okazało się jednak, że niewystarczająca ilość miejsc składowych nie miała znaczenia przy niezgodnościach estetycznych, ponieważ pracownicy umiejętnie składowali półwyroby na polach odkładczych, co ograniczało powstanie rys z tego powodu. Zbadano możliwość powstania zarysowań poduszek przez pracowników. Okazało się, że zarysowania mogły być spowodowane poprzez niezakładanie przez pracowników rękawiczek. Sprawdzono instrukcje stanowiskowe i nie znaleziono tam zapisu o konieczności używania rękawiczek. Stwierdzono, że tutaj leży przyczyna źródłowa problemu z zarysowaniami. Po wprowadzeniu konieczności zakładania rękawiczek zminimalizowano wystąpienia zarysowań o ok. $70 \%$.

Wnioski z przeprowadzonej analizy dla analizowanego przedsiębiorstwa są następujące: aby utrzymać rezultat wprowadzonych zmian, kierownictwo badanego przedsiębiorstwa powinno egzekwować przestrzeganie zasad BHP przez podwładnych, przypominać o istotnych zapisach $\mathrm{w}$ instrukcjach stanowiskowych w tym zakresie, co powinno skutecznie zredukować straty finansowe w związku z zarysowaniami powierzchni poduszek powietrznych.

\section{Podsumowanie}

Celem artykułu było wykazanie, że wyniki z kontroli wizualnej poduszek powietrznych można wykorzystać do doskonalenia procesu produkcyjnego. W ramach analizy wyników z kontroli wizualnej wykorzystano wybrane narzędzia i metody, zarówno te ilościowe, jak i jakościowe celem udoskonalenia procesu produkcyjnego. Skorzystano z diagramu Pareto-Lorenza, dzięki czemu udało się poznać strukturę niezgodności poduszek powietrznych. Zidentyfikowane dzięki diagramowi Pareto niezgodności krytyczne zostały wykryte za pomocą kontroli wizualnej, w tym najczęściej występująca - niezgodność estetyczna - za sprawą kontroli wzrokowej. Dla stwierdzonej niezgodności najczęściej występującej podjęto próbę szerszej identyfikacji tego problemu stosując metodę $5 \mathrm{~W} 1 \mathrm{H}$ oraz wykrycia przyczyny źródłowej jego powstania wykorzystując w tym celu metodę 5WHY (a dokładniej: diagram WHY-WHY). Przeprowadzone analizy przyniosły zamierzone rezultaty i udało się poznać przyczynę fundamentalną powstania krytycznej niezgodności, co umożliwiło podjęcie działań korygujących. Wprowadzone działania naprawcze przyniosły wymierny skutek, ponieważ w znaczący sposób ograniczyły wystąpienie danej niezgodności krytycznej.

Reasumując uzyskane wyniki, należy stwierdzić, że kontrola wizualna może w istotny sposób wpływać na doskonalenie procesu produkcji, ponieważ dzięki 
odpowiedniej analizie wyników z kontroli jakości, np. analizie struktury niezgodności i ich przyczyn, następnie określeniu właściwych działań korygujących oraz ciągłemu monitorowaniu sytuacji po wprowadzonych działaniach naprawczych, można znaczenie ograniczyć lub nawet zapobiec występowaniu problemów jakościowych w przyszłości. Kontrola wizualna może istotnie współtworzyć wartość dodaną do procesu, co udowodniono w prezentowanym artykule. Należy podkreślić, że aby tak było, wyniki z kontroli wizualnej muszą być wiarygodne, bez błędów oceny zgodności, bo błędy te, w postaci nieprawidłowej klasyfikacji wyrobu do kategorii $\mathrm{OK}, \mathrm{nOK}$, mogą przyczynić się do pogorszenia efektywności procesu produkcyjnego $[16,17]$. Tej kwestii nie sprawdzono, co niewątpliwie należałoby zrobić.

\section{Bibliografia}

[1] R. Kolman. Poradnik kontrolera jakości. Bydgoszcz: TNOiK: Oficyna Wydawnicza Ośrodka Postępu Organizacyjnego, 1998.

[2] K. Knop, S. Borkowski. Kontrola jakości. Teoria i praktyka. Zawiercie: AXON, 2017.

[3] M. Kwaśniewski. Widzenie maszynowe - nowe zastosowania, 2015. Pobrano z: http://sluzby-ur.pl/artykuly/491/widzenie_maszynowe_nowe_zastosowania.html (dostęp: 12.05.2018).

[4] M. Diering, K. Dyczkowski, A. Hamrol. Szacowanie poziomu zgodności ocen w kontroli wizualnej - problemy $w$ wyznaczaniu wspótczynników typu Kappa. Konferencja Innowacje w Zarządzaniu i Inżynierii Produkcji. Część IX. Inżynieria Jakości Produkcji i Usług, 2015. Pobrane z: http://www.ptzp.org.pl/files/konferencje/kzz/artyk_pdf_2015/T2/t2_0257.pdf (dostęp: 18.06.2018).

[5] J. Rewilak. Czy ufasz kontroli wzrokowej?, $2010 . \quad$ Pobrane z: http://szkolenia.tqmsoftcom/inspekcja (dostęp: 20.03.2013).

[6] T. Giesko, A. Mazurkiewicz, A. Zbrowski. Optomechatroniczny system do automatycznej kontroli jakości wyrobów w przemyśle. Problemy eksploatacji, $\mathrm{Nr} 4$, 2011 , 103-114. Pobrano z: http://yadda.icm.edu.pl/yadda/element/bwmeta1.element.baztech-article-BAR0-00600085 pdf (dostęp: 18.06.2018).

[7] I. Durlik. Inżynieria zarzadzania. Część 1. Strategie organizacji produkcji. Nowe koncepcje zarzadzania. Warszawa: PWN, 2017.

[8] L. Dwiliński. Zarzadzanie produkcja. Warszawa: Oficyna Wydawnicza Politechniki Warszawskiej, 2002.

[9] B. R. Kuc. Kontrola jako funkcja zarzadzania. Warszawa: Difin, 2009.

[10]A. Bieńkowska, Z. Kral. Kontroling jakości jako nowoczesna metoda wspomagania $i$ koordynacji wspomagania jakościq. Problemy jakości, 10, 1998, 7-13.

[11]A. Hamrol. Zarządzanie jakościa z przykładami. Warszawa: PWN, 2006. 
[12]B. Czyżewski, J. Potęga. Narzędzia analizy i doskonalenia jakości. Poznań: Wielkopolski Klub Jakości FSNT NOT, 2007.

[13]A. Mydlarz. 5W2H - lepiej mądrze stać, niż głupio biegać - perspektywa problemu, 2017. Pobrane z: http://inzynierjakosci.pl/2017/12/5w2h-przyklad-opis-metody/ (dostęp: 10.06.2018).

[14]M. Ingaldi, K. Nowakowska. Wykorzystanie metody 5W2H do doskonalenia produkcji wentylatorów. Archiwum Wiedzy Inżynierskiej, Tom 1, nr 1 (2016), s. 39-41.

[15]A. Lis, Kowal K., M. Brożyńska, M. Szymczak. $5 x$ dlaczego. Pierwszy podręcznik metody. 2K Consulting, 2014.

[16]M. Bożek, M. Rogalewicz. Nieskuteczność kontroli końcowej przyczyna niskiej efektywności procesu wytwarzania. Inżynieria Maszyn, R. 18, z. 1, 2013, 84-96.

[17]M. Diernig, A. Kujawińska. MSA - Analiza Systemów Pomiarowych. Przewodnik po procedurach. Poznań: AR Comprint, 2012.

\title{
ANALYSIS AND EVALUATION OF THE RESULTS FROM THE VISUAL INSPECTION PROCESSES AS A METHOD OF IMPROVING THE MANUFACTURING PROCESS OF AIRBAGS
}

\begin{abstract}
The presented article is a case-study on improving the production process of airbags, where the results of visual inspection processes of the analysed product were used to initiate the improvement. The article presents the results of the analysis of the non-conformity structure of the tested product, on the basis of which critical nonconformities were identified. For this purpose, the Pareto-Lorenz diagram was used. The most frequent nonconformities of the analysed product are scratches on the surface of the airbags, which is detected by visual inspection. To analyze the critical nonconformities, methods such as $5 \mathrm{~W} 1 \mathrm{H}, 5 \mathrm{WHY}$ were used. The $5 \mathrm{~W} 1 \mathrm{H}$ method allowed to better recognize the studied "critical" problem. In turn, thanks to the 5WHY method, and more precisely its version in the form of the WHY-WHY diagram, the root cause of the problem was indicated, for which remedial action was proposed. The analyzes carried out proved that thanks to the analysis of the results from the quality control (visual inspection) it is possible to limit the occurrence of quality problems and thus improve the production process.
\end{abstract}

Key words: visual inspection, improvement, root cause analysis, automotive industry, airbags.

Data przestania publikacji do Redakcji: 25.06 .2018 Data akceptacji publikacji przez Redakcję: 30.07.2018 